\title{
USING THE CAREER ORIENTATIONS INVENTORY (COI) FOR MEASURING INTERNAL CAREER ORIENTATIONS IN THE SOUTH AfRican ORGanisational CONTEXT
}

\author{
Authors: \\ Melinde Coetzee ${ }^{1}$ \\ Dries Schreuder ${ }^{1}$

\section{Affiliations:} \\ ${ }^{1}$ Department of \\ Industrial and \\ Organisational \\ Psychology, University of \\ South Africa, South Africa \\ Correspondence to: \\ Melinde Coetzee \\ e-mail: \\ coetzm1@unisa.ac.za
}

Postal address:

Department of Industrial and Organisational

Psychology, PO Box 392,

UNISA, Pretoria, Gauteng, 0003, South Africa

\section{Keywords:}

autonomy/independence; career anchors;

career orientations;

entrepreneurial

creativity; technical/

functional competence

\section{Dates:}

Received: 02 Feb. 2009

Accepted: 23 Apr. 2009

Published: 17 July 2009

How to cite this article:

Coetzee, M., \& Schreuder, D. (2009). Using the career orientations inventory (COI) for measuring internal career orientations in the South African organisational context. SA Journal of Industrial Psychology/SA Tydskrif vir Bedryfsielkunde, 35(1), Art. \#806, 13 pages. DOI: 10.4102/sajip.v35i1.806

This article is available at: http://www.sajip.co.za

\footnotetext{
(C) 2009. The Authors. Licensee: OpenJournals Publishing. This work is licensed under the Creative Commons Attribution License.
}

\begin{abstract}
This study investigated the use of the Career Orientations Inventory as a measure to determine the career orientations of a random sample of 2978 participants at predominantly managerial and supervisory level in the service industry. Whereas an exploratory factor analysis yielded a ninefactor structure, a confirmatory factor analysis confirmed five constructs as measures of the career orientations domain. A similar factorial pattern was observed across the African and white groups and a weaker factorial pattern across the Indian and coloured groups. The findings of this study contribute valuable new knowledge to both the practice and the field of Career Psychology.
\end{abstract}

\section{INTRODUCTION}

Changes in the organisation of work and in the composition of the labour force have combined to change the content, processes and consumers of career interventions and services in the workplace (Kniveton, 2004). Nations across the world are finding themselves in the midst of comprehensive economic, political and social transitions. As they compete for economic viability in a global economy, the quality and purposefulness of their human resources become fundamental concerns in their policies and legislation (Herr, Cramer \& Niles, 2004). Whether a nation's purpose is to build human capital, match persons and occupations, retain scarce and critical skills, increase the employability of its employees or develop their general, professional and technical skills capacity, models of career development interventions tailored to such goals are being developed, refined and implemented (Fugate, Kinicki \& Ashforth, 2004; Herr et al., 2004; Kuijpers \& Scheerens, 2006).

Moreover, changes in the organisation of work are also changing conceptions of individual career development. New career paths are being forecast that are far more dependent on individual career management than on institutional management of employees' careers (Herr et al., 2004). As individuals start to take more ownership of their careers, the focus on the subjective or inner career becomes increasingly more important than the more objective, organisationally defined career (Derr \& Briscoe, 2007; Hall, 1976). Whereas the internal career is a self-definition of career success as it is more subjective, long term and stable and represents life goals as well as work goals, the external career is an organisational or professional definition of career success that is more short term, unpredictable and fast-changing (Derr \& Briscoe, 2007). Researchers such as Derr (1986), Driver (1982) and Schein $(1975 ; 1978)$ have also extensively explored the internal career paradigm and found that people differ significantly in the way they think about their careers. Moreover, their research suggests that people's career choices and experiences of subjective career success are driven by a set of master career motives that seem to form part of the career self-concept or inner career orientation. These master motives act as a cognitive compass (Fugate et al., 2004) that motivates and pulls people towards (or constrains them from) specific career choices and decisions (Schein, 1978; 1990).

Another prominent trend in career research is the increasing shift in the way people define their careers from a psychological point of view. The concept of career is being challenged by social and economic pressures that in turn affect the beliefs that individuals hold about themselves, the people around them and the world of work generally (Bruck, Allen \& Spector, 2002; Havran, Visser \& Crous, 2003). In this regard, research shows a general increase in the focus on the career as a means of enhancing personal lifestyles and achieving greater autonomy and freedom from particular work roles (Coetzee \& Schreuder, 2008; Guest \& Sturges, 2007). The younger working generation also appears to hold different values from those of their older colleagues in the sense that they appear to prefer developing and managing their careers on their own terms, as opposed to following traditional hierarchical norms (Cannon, 1995).

Contemporary career studies also show that younger employees increasingly tend to seek lateral rather than hierarchical paths, and that these paths are upheld by their career anchors or orientations and values (Marshall \& Bonner, 2003). Here research has shown that people make decisions to forge their own career paths rather than to conform to expectations, because doing so helps them to better honour their own values and preferences (Casey \& Alach, 2004; Hewlett \& Luce, 2005; Valcour, Bailyn \& Quijada, 2007). Recent research by Havran et al. (2003) also reported different factor structures underlying the originally hypothesised career orientations model of Derr (1986), pointing to a shift in focus for careerists towards a need to pursue personal interests along with meaningful work. Research by Marshall and Bonner (2003) also indicated a similar shift of values and motivations across all workplace cultures, with these shifts being reflected in their inner career orientations.

In agreement with the foregoing, researchers in the careers field have stated that the attention given to individuals' inner definitions of career success (as defined by their career orientations), as a means of predicting employees' organisational commitment, job satisfaction, motivation and performance, is a prominent trend in organisations today (Coetzee et al., 2007; Havran et al., 2003; Kanye \& Crous, 2007). 
Organisations that endeavour to retain valuable employees are therefore urged to provide incentives and career paths that are consistent with the career values, expectations and aspirations that underlie the career orientations of these employees (Järlström, 2000; Schein, 1996; Suutari \& Taka, 2004). If there is no fit between employees' inner career orientations and their job environment, the result may well be anxiety, stress, job dissatisfaction and turnover (Feldman \& Bolino, 1996; Jiang \& Klein, 2000; Jiang, Klein \& Balloun, 2001). Moreover, from an organisation's perspective, research on career orientations is needed to guide current selection, placement, development, reward and retention practices (Ramakrishna \& Potosky, 2002).

\section{Career anchors: Theory}

The concept of a career anchor refers to a pattern of self-perceived talents and abilities, basic values, and the evolved sense of motives and needs (as they pertain to the career) that influences a person's career-related decisions (Schein 1974; 1975; 1978; 1996). The conceptual model associated with Schein's (1978) career anchor theory is best understood in terms of a person's career self-concept, which develops as a person gains life experience. As individuals are required to make choices related to their selfdevelopment, family or career, they may become more aware of the values and motives that frame the choices they make. In other words, an individual's career self-concept acts as a stabilising force; when an important life (or career) choice needs to be made, there are certain concerns, needs or values that the individual will not give up (Schein, 1975).

Research by Schein $(1978 ; 1990 ; 1996)$ suggests that most people's career self-concepts (motives and values) are grounded in eight categories or anchors: (1) autonomy/independence, which includes a person's need to be free of organisational constraints in order to pursue professional competence; (2) technical/functional competence, which is the motivation to develop one's technical or functional knowledge and expert skill; (3) general managerial competence, which can be described as the desire to attain a position that requires the application of interpersonal, political, analytical and financial skills associated with management; (4) entrepreneurial/creativity, the need to create or build (rather than manage) something that is entirely one's own project; (5) lifestyle, the need to integrate work, family, and self-concerns into a coherent lifestyle; (6) pure challenge, the need to test one's abilities by single-mindedly focusing on competing with extremely tough opponents and solving a variety of challenging problems; (7) service/dedication to a cause, the need to align work activities with personal skills and values related to helping society and to improve the world in some fashion; and (8) security/stability, the need for job security (associated with benefit packages and long-term employment) in an organisation and stability in a geographical area. Research by DeLong (1982b) and Custodio (2004) found that the security/stability anchor emerged as two independent career anchors. One represents the need for organisational stability (long-term employment). The other represents individuals' concern with permanence of geographic location.

Although Schein (1978) argued that, by definition, an individual can maintain only one dominant career anchor, his own and other empirical evidence suggests that individuals can have more than one strong career anchor (Coetzee \& Schreuder, 2008; Feldman \& Bolino 1996; Ramakrishna \& Potosky 2003; Schein, 1996). According to DeLong (1982a; 1982b) and Butler and Waldroop (1999), one to three anchors tend to cluster together to form an individual's career and work preferences. These composites of the eight categories of career anchors explain why people stay engaged in a certain job or are committed to an organisation (Butler \& Waldroop, 1999). Moreover, since the career anchors model describes a highly individualised process of value development based upon a person's own experiences, the extent to which certain occupational groups come to possess certain dominant career anchors is likely to be due to self-selection into and out of those occupations by individuals (Schein, 1975; Ramakrishna \& Potosky, 2002). Organisations and occupational groups themselves are not likely to cause individuals to maintain or abandon pre-determined anchors (Ramakrishna \& Potosky, 2002).

Career anchors have been studied widely in different occupations and in different contexts, countries and companies (Erdoğmus 2003). However, research on career anchors in the South African context has mostly focused on predominantly white samples (Boshoff, Bennet \& Kellerman, 1994; Erwee, 1990; Rothmann, 2001; Schenk, 1987; Schreuder, 1989; Van Vuuren, 1986) and only recently on predominantly black samples (Coetzee, Schreuder \& Tladinyane, 2007; Coetzee \& Schreuder, 2008). Moreover, upto-date career anchors research in South Africa on the structural equivalence of the Career Orientations Inventory (COI) seems to be lacking. In addition, career anchors studies have also been criticised as concentrating on small samples and being studies of particular, interesting and illustrative cases (Erdoğmus, 2003). Researchers have also pointed out that the empirical validation of Schein's (1978) career anchor classification deserves further attention due to the inconsistency of results (Custodio, 2004; Feldman \& Bolino, 1996; Suutari \& Taka, 2004).

In view of the foregoing, Coetzee and Schreuder (2008) found that with the exception of the entrepreneurial career anchor, black people and white people show similar career anchor preferences. On the other hand, findings of a study conducted by Coetzee et al. (2007) suggest that black people and white people differ regarding their career orientations. In view of these seemingly contradictory findings and given the apparent importance of understanding employees' inner career orientations, it was regarded as important to investigate further the career orientations of various ethnic groups in the South African organisational context. For the purpose of this study, the following hypotheses were therefore formulated:

H1: The factor structure underlying the theoretical eight-factor career anchor model developed by Schein (1978) applies equally across various ethnic groups in the multi-cultural South African organisational context.

H2: The research-version of the COI (developed by Schein, in collaboration with DeLong, 1982a; 1982b) can be applied as a measure to determine the career orientations of working adults in the South African organisational context.

\section{AIMS OF THE STUDY}

In view of the stated research hypotheses, this research set out to investigate the use of the research version of the COI (developed by Schein, in collaboration with DeLong, 1982a; 1982b), as a measure to determine the career orientations of working adults in the South African organisational context. More specifically, the objective was to investigate whether the factor structure underlying the theoretical eight-factor career anchor model developed by Schein (1978) applies equally across various ethnic groups in the multi-cultural South African organisational context.

It should be noted that in the context of this study the emphasis is on the construct career orientation as a central part of the concept of career anchors. This is also in line with other research on career anchors conducted by, for example, Custodio (2004), Coetzee and Schreuder (2008) and Ramakrishna and Potosky (2002). In an attempt to validate and refine Schein's (1978) career anchor model, DeLong (1982b) found that the COI measured the career motives, values and needs of individuals, but did not reflect individuals' perception of their talents. Schein (1990) agrees with the view that the construct career anchors can be measured by means of a combination of the COI and a structured in-depth interview exercise.

Considering the empirical limitations of the $\mathrm{COI}$ and the fact that the internal career orientations of, in particular, black people in 
the multi-cultural South African organisational context are under-researched, the findings of this study are expected to contribute valuable new knowledge to both the practice and the field of Career Psychology.

\section{Research approach}

\section{RESEARCH DESIGN}

For this exploratory pilot study, a survey design was used to achieve the research objective (Shaughnessy \& Zechmeister, 2003). The advantages of the survey research approach include savings of time and money, lack of interviewer bias, obtaining accurate results, more privacy for participants, and the fact that samples need not be very large in relation to the population (Salkind, 1997). The major disadvantage of this design is that findings can only be generalised to the sampled population at the time of the survey (Dooley, 1995).

\section{Research method \\ Participants}

The participants were a random sample of students registered across various fields of study at a distance learning higher education institution for a particular year. The total sample of 2978 students constituted $58 \%$ females and $42 \%$ males. In terms of race, the sample was represented by $67 \%$ black students $(1$ 592 Africans; 224 Indians; 186 coloureds) and 976 white students $(33 \%)$. In terms of marital status, $52 \%$ were single, $42 \%$ were married, $1 \%$ were widowed and $5 \%$ were divorced. The age groups were represented as follows: 25 years and younger - $28 \%$; 26 to 30 years $-20 \%$; 31 to 40 years - $34 \%$; 41 to 55 years - $16 \%$ and 56 years and older $-1 \%$. The mean age of the participants was 32, which implies well-established internal career orientations, motives and values (Schein, 1996).

In terms of educational level, $26 \%$ had a grade 12 qualification, $15 \%$ had completed their first year of higher education studies, $13 \%$ were in their second year and $8 \%$ were in their third year of studies. $22 \%$ had a diploma whilst $13 \%$ already had a degree. Students with a post-graduate qualification represented only $3 \%$ of the sample. With regard to occupational status, $80 \%$ of the participants were in full-time employment, $12 \%$ in part-time employment, $5 \%$ were self-employed and $3 \%$ were engaged in voluntary work, contract work or internships. Positions occupied by the participants constituted predominantly $18 \%$ at senior and middle management level, $54 \%$ at middle- and firstlevel supervisory level and $28 \%$ in non-managerial positions.

The following economic sectors were represented: $35 \%$ government; $15 \%$ services; $18 \%$ financial, insurance, real-estates and business; $7 \%$ wholesale and retail; $6 \%$ transport, storage and communication and $19 \%$ other sectors such as agriculture, mining, manufacturing, electricity/gas and construction. The predominant fields of expertise reported by the participants were as follows: the financial field (including accounting, auditing, banking, economics) $21 \%$; education $11 \%$; human resource management $9 \%$; protective services (SAPS; security, military) $9 \%$; healthcare $8 \%$; marketing/media/communication $6 \%$; public administration $6 \%$; IT 5\%; legal/law 3\%; retail/sales $5 \%$; and catering/hospitality $2 \%$.

\section{Measuring instrument: Career Orientations Inventory (COI)}

As mentioned previously, the research version of the Career Orientations Inventory (COI) developed by Schein in collaboration with DeLong (1982a; 1982b) was used to measure the variables of concern to this study. The COI (DeLong, 1982a; $1982 b)$ is a self-rated measure containing 41 items. To avoid neutral answers, a 10-point Likert-type scale was used for subject responses on each of the 41 items. Based on Schein's (1974; 1978) eight career anchors model these items related to perceived importance and agreement of statements. Total scores obtained for each of the eight categories of career anchors were summed up and averaged to yield an individual score for each career anchor. The COI provides a pretested instrument with demonstrated high internal validity and reliability (Burke, 1983; Custodio, 2004; DeLong, 1982a; 1982b; Wood, Winston \& Polkosnik, 1985). Custodio (2004) reports Cronbach alpha reliability coefficients ranging from 0.78 to 0.84 , while Coetzee and Schreuder (2008) report Cronbach alpha coefficients ranging from 0.46 (lifestyle) to 0.85 (entrepreneurial creativity). Since the purpose of this study was not to make individual predictions based on the COI, but rather to investigate broad trends and the structural equivalence of the COI, the instrument was considered to be psychometrically acceptable.

\section{Research procedure}

Questionnaires were posted to a randomly selected number of 60000 students who were registered at the higher education institution for the particular year using the postal facilities of the institution. Each questionnaire included a covering letter inviting subjects to participate in the study and assuring them that their individual responses would remain confidential. Participants were asked to complete the questionnaires and return them by mail to the researchers using the return envelope. A sample of 2 978 usable questionnaires was returned. The questionnaires were scored electronically according to the author's instructions.

\section{Statistical analysis}

The statistical procedures chosen for this research were based on their applicability to the exploratory nature of the research design. The statistical analysis was carried out with the help of the SPSS LISREL statistical package and consisted of three steps. The first step was to examine the factor structure of the COI variables by means of exploratory factor analyses (EFA). The second step involved estimating the internal consistency reliabilities of the scales and subscales derived by means of the factor analyses and computing the inter-correlations between the scales. In the third step, a multi-group confirmatory factor analysis (CFA) was performed on the original COI for the total sample and the best-fit COI model for the various race groups.

\section{Exploratory factor analysis (EFA)}

EFA was performed to examine the dimensionality of the COI and to determine whether a single factor or multiple factors accounted for the variance in the items of the questionnaire. Before proceeding, it was necessary to determine whether the sample was adequate for performing such an analysis. It was also necessary to establish whether there were a sufficient number of substantial correlations between the COI scales to merit factor analysis. The principal axis factoring (PAF) extraction method and direct oblique rotation were subsequently performed to determine the hypothesised factor solutions for the COI (De Long, 1982b; Schein, 1978). Cronbach alpha coefficients were determined for each of the obtained factors and items that did not contribute to the factor pattern were excluded in the final analyses.

In accordance with the rational construct approach, the defined theoretical constructs were used to determine the number of factors for rotation purposes (Owen, 1995). The distinction between creating and testing hypotheses in factor analysis is not definite (Child, 1990). The criteria mentioned below guided the number of factors to be extracted:

- $\quad$ statistical criteria conventionally used, such as Kaiser's eigenvalue-larger-than-one-criterion

- the theoretical expectation regarding the number of factors and interpretability of the obtained factors

- the number of significant factors $(p<0.01)$ and the proportion of variance explained; and any given item being considered to belong to a particular factor if it had a factor loading of 0.30 or higher. 
Theoretical expectations and the contents of factors and items were considered when decisions to include or omit items were not clear-cut.

After considering the limitations of EFA, it was decided that a confirmatory factor analysis (CFA) would be performed as the use of CFA allows researchers to formulate and directly test competing hypotheses regarding the underlying factor structure (Strasheim, 2008). The limitations of EFA are that if the predicted factor solution is not found, two interpretations are possible: firstly, there are true differences between the actual and predicted factor structure; or, secondly, the EFA was unable to uncover the hypothesised structure. The most troublesome difficulty with EFA is selecting the appropriate underlying dimensionality.

\section{Confirmatory factor analysis (CFA)}

The CFA has strong links with structural equation modelling (SEM). As a confirmatory approach, a model is postulated, based on theory and empirical evidence from previous research. In the context of this study, the first model therefore represented the original measurement instrument as postulated by the developers (DeLong, 1982b; Schein, 1978;) of the COI scale. The original eight-factor model was then tested in a single group analysis, using SEM goodness-of-fit tests to determine whether the pattern of variances and covariances in the data was consistent with the postulated theoretical model (Garson, 2008). The SEM process is generally used to conduct the CFA as it focuses on validating the measurement model by obtaining estimates of the parameters of the model and by assessing whether the model itself provides a good fit to the data (Garson, 2008)

To investigate lack-of-fit, each sub-scale or dimension is then evaluated individually. In the context of this study, the face validity of each item as a measure of the proposed dimension was firstly evaluated. Secondly, the reliability of each dimension was evaluated, and items that lowered the reliability of the dimension were then removed until all items within the dimension did not lower the reliability. Subsequent to the reliability analysis, a second model was then tested. This model excluded the items that were indicated to perform poorly in the item-reliability analyses, and also excluded the dimensions that did not perform well. Moreover, in the case of testing the second model, it was regarded as appropriate that the equivalence of Model 2 be tested across the four race groups represented in this study (especially because of potential differences between the race groups). This resulted in four ethnic groups, namely Africans $(n=1592)$, Indians $(n=224)$, coloureds $(n=186)$ and whites $(n=976)$ in the multiple groups CFA.

The advantage of using multi-group CFA by following a SEM approach is that a wide variety of hypotheses of equivalence levels across groups can be tested (Vandenberg \& Lance, 2000). The first hypothesis tests whether the factor pattern is similar across groups. If this hypothesis is tenable, the second hypothesis tests whether the factor loadings are invariant (equal). If this hypothesis is not rejected, the third hypothesis tests whether variances of the latent variables and covariances between the latent variables are invariant. The fourth hypothesis tests whether error variances are equal (Byrne, 1998). When all four of these hypotheses are tenable, it can be concluded that the measurement instrument is invariant (and by implication equivalent) across cultural or ethnic groups (Strasheim, 2008).

The model adequacy was evaluated by means of goodness-offit measures. Goodness-of-fit tests determine whether the model being tested should be accepted or rejected (Garson, 2008). The model chi-square was used as it is the most common goodnessof-fit test when comparing models (Strasheim, 2008). With the chi-square, the difference between the observed data and the hypothesised model is tested (Garson, 2008). A significant chisquare indicates lack of satisfactory model fit, whilst a non- significant chi-square indicates a good model fit. However, a limitation of the chi-square test is that the size of the sample has an impact on chi-square values. Garson (2008) suggests that if the sample is large (as in the case of this study), even small differences between the model and the data will result in a statistical significance. Hence with large samples the chi-square will almost certainly be significant (Hox \& Bechger, 1998). A variety of alternative fit indices have therefore been proposed by researchers (Garson, 2008; Hu \& Bentler, 1999). All goodnessof-fit measures are some function of the chi-square and degrees of freedom. These alternative indices consider not only the fit of the model but also its simplicity. Even though the goodnessof-fit indices still depend on sample size and distribution, the dependency is much smaller than that of the routine chi-square test (Hox \& Bechger, 1998)

The Goodness-of-Fit Index (GFI) indicates the relative amount of the variances/covariances in the sample predicted by the estimates of the population. In addition, the Adjusted Goodnessof-Fit Index (AGFI) is a measure of the relative amount of variance accounted for by the model, corrected for the degrees of freedom in the model relative to the number of variables. GFI and AGFI range between 0 and 1 , and when models fit well, these indices will be closer to 1.00. The Parsimony Normed Fit Index (PNFI) addresses the issue of parsimony in SEM (Strasheim, 2008). By arbitrary convention, PNFI $>0.60$ indicates good parsimonious fit (Garson, 2008)

The Comparative Fit Index (CFI) represents the class of incremental fit indices in that it is derived from the comparison of a restricted model (that is, one in which structure is imposed on the data) with that of an independence (or null) model (that is, one in which all correlations among variables are zero) in the determination of goodness-of-fit. The Non-Normed Fit Index (NNFI) is a relative measure of covariation explained by the model (Garson, 2008). For these fit indexes (CFI and NNFI), it is more or less generally accepted that a value of less than 0.90 indicates that the fit of the model can be improved (Hoyle, 1995), although a revised cut-off value close to 0.95 has been advised by $\mathrm{Hu}$ and Bentler (1999).

To overcome the problem of sample size, Brown and Cudeck (1993) suggest using the Root Mean Square Error of Approximation (RMSEA) and the $90 \%$ confidence interval of the RMSEA. The primary principle of the RMSEA is that it evaluates the extent to which the model fails to fit the data. The RMSEA estimates the overall amount of error; it is a function of the fitting function value relative to the degrees of freedom. The RMSEA point estimate should be 0.05 or less and the upper limit of the confidence interval should not exceed 0.08 (Raykov \& Marcoulides, 2000). Hu and Bentler (1999) suggested a value of 0.06 to be indicative of good fit between the hypothesised model and the observed data. Fabrigar, Wegener, MacCallum and Strahan (1999) elaborated on these cut-off points and noted that RMSEA values ranging from 0.08 to 0.10 indicate mediocre fit, and those greater than 0.10 indicate poor fit. In the context of this study, Standardised Root Mean Square Residual (SRMR) was also used as a goodness-of-fit measure in the multi-group CFA. A value less than 0.05 is widely considered good fit and below 0.08 adequate fit to indicate tenable hypotheses (Garson, 2008; Hu \& Bentler, 1999).

The Bayesian Information Criterion (BIC) is very useful as a criterion when non-nested models are evaluated. If the BIC value is equal to zero or the smaller the BIC values (implying larger negative numbers), it can be said that the model fits as well as the saturated model. If the BIC values are positive, the model fits worse than the saturated model. An advantage of the BIC is that it can be used to compare different models, and it does not require the models to be nested as is necessary with chi-square difference tests (Raftery, 1995). 


\section{RESULTS}

\section{Exploratory factor analyis (EFA)}

As mentioned previously, the COI developed by Schein (1978), and refined by DeLong (1982a; 1982b), consists of 41 items measuring self-perceived internal career orientations relating to respondents' master career motives or drives. The items from the COI were presented to respondents in two sections. These sections consisted of: (1) the items related to perceived importance of (21 items); and (2) items related to agreement (20 items). The items related to technical and managerial skills in the workplace, as well as a perceived need for attributes of autonomy, security of job and geographical stability, lifestyle and work/family balance, creativity and entrepreneurship, challenge, technical and functional expertise, and service in job roles (including utilising one's talents and skills, including interpersonal and helping skills in the service of an important cause). As stated previously, Schein (1978) identified five career anchors through these items (technical/functional; general managerial competence; autonomy/independence; security/ stability; and entrepreneurial/creativity). Further research by Derr (1980) and DeLong (1982a; 1982b) identified another three categories (service/dedication to a cause, pure challenge, and lifestyle).

The Kaiser-Meyer-Olkin measure of sampling adequacy for section 1 was equal to 0.85 , exceeding the recommended minimum value of 0.60 . The Bartlett's test of sphericity yielded a statistically significant approximate chi-square significant at $p<0.001$, supporting the factorability of the correlation matrix. Items that did not improve the item-total correlation and that did not contribute to the factor pattern were excluded in the final analysis. Similarly, the Kaiser-Meyer-Olkin measure of sampling adequacy for section 2 was equal to 0.80 , exceeding the recommended minimum value of 0.60 .

TABLE 1

EFA rotated factor matrix Principal axis factoring with varimax rotation section 1-importance

\begin{tabular}{|c|c|c|c|c|c|}
\hline COI ITEMS & $\begin{array}{c}\text { FACTOR } \\
1 \\
\end{array}$ & $\begin{array}{c}\text { FACTOR } \\
2 \\
\end{array}$ & $\begin{array}{c}\text { FACTOR } \\
3 \\
\end{array}$ & $\begin{array}{c}\text { FACTOR } \\
4\end{array}$ & $\begin{array}{c}\text { FACTOR } \\
5\end{array}$ \\
\hline MCE-Q10 & 0.79 & & & & \\
\hline MCE-Q18 & 0.69 & & & & \\
\hline MCE-Q2 & 0.60 & & & & \\
\hline MCE-Q16 & 0.58 & & & & \\
\hline MCE-Q14 & 0.50 & & & & \\
\hline MCE-Q8 & 0.43 & & & & \\
\hline SE-Q13 & & 0.76 & & & \\
\hline SE-Q21 & & 0.68 & & & \\
\hline SE-Q5 & & 0.58 & & & \\
\hline Al-Q11 & & & 0.67 & & \\
\hline Al-Q3 & & & 0.66 & & \\
\hline Al-Q19 & & & 0.59 & & \\
\hline SS-Q4 & & & & 0.79 & \\
\hline SS-Q12 & & & & 0.65 & \\
\hline TF-Q17 & & & & & 0.72 \\
\hline TF-Q9 & & & & & 0.54 \\
\hline $\begin{array}{l}\text { Cumulative } \\
\text { percentage } \\
\text { variance } \\
\text { explained }\end{array}$ & 15.02 & 23.35 & 34.29 & 42.09 & 47.76 \\
\hline $\begin{array}{l}\text { MCE: Managen } \\
\text { SE: Service/De } \\
\text { Al: Autonomy/ln } \\
\text { SS: Security/St } \\
\text { F: Technical/F }\end{array}$ & $\begin{array}{l}\text { /Competitiv } \\
\text { tion to a cal } \\
\text { endence } \\
\text { ty } \\
\text { tional }\end{array}$ & & & & \\
\hline
\end{tabular}

TABLE 2

EFA rotated factor matrix:

Principal axis factoring with varimax rotation section 2-agreement

\begin{tabular}{|c|c|c|c|c|}
\hline COI ITEMS & FACTOR 6 & FACTOR 7 & FACTOR 8 & FACTOR 9 \\
\hline GMP-Q34 & 0.62 & & & \\
\hline GMP-Q30 & 0.59 & & & \\
\hline GMP-Q38 & 0.54 & & & \\
\hline GMP-Q26 & 0.53 & & & \\
\hline GMP-Q22 & 0.42 & & & \\
\hline EC-Q40 & & 0.83 & & \\
\hline EC-Q24 & & 0.76 & & \\
\hline EC-Q32 & & 0.52 & & \\
\hline GS-Q41 & & & 0.81 & \\
\hline GS-Q28 & & & 0.76 & \\
\hline LAI-Q31 & & & & 0.63 \\
\hline LAI-Q27 & & & & 0.52 \\
\hline LAI-Q35 & & & & 0.43 \\
\hline LAI-Q39 & & & & 0.39 \\
\hline $\begin{array}{l}\text { Cumulative } \\
\text { percentage } \\
\text { variance } \\
\text { explained }\end{array}$ & 13.57 & 25.57 & 35.26 & 44.01 \\
\hline
\end{tabular}

GMP: General management/Pure Challenge

EC: Entrepreneurial/Creativity

GS: Geographical stability

LAI: Lifestyle/Autonomy/Independence

TABLE 3

EFA: Descriptive statistics: Reliability, means, standard deviations

\begin{tabular}{|c|c|c|c|c|c|}
\hline FACTOR & DIMENSION & $\begin{array}{l}\text { NO. OF } \\
\text { ITEMS }\end{array}$ & $\begin{array}{r}\text { CRONBACH } \\
\text { ALPHA } \\
\text { COEFFICIENT }\end{array}$ & MEAN & SD \\
\hline 1 & $\begin{array}{l}\text { Management/ } \\
\text { Competitiveness/ } \\
\text { Entrepreneurial }\end{array}$ & 6 & 0.79 & 43.77 & 10.43 \\
\hline 2 & $\begin{array}{l}\text { Service/Dedication to } \\
\text { a cause }\end{array}$ & 3 & 0.74 & 26.63 & 3.57 \\
\hline 3 & $\begin{array}{l}\text { Autonomy/ } \\
\text { Independence }\end{array}$ & 3 & 0.70 & 19.45 & 6.08 \\
\hline 4 & Security/Stability & 2 & 0.76 & 17.21 & 3.31 \\
\hline 5 & Technical/Functional & 2 & 0.58 & 12.74 & 4.35 \\
\hline \multicolumn{2}{|c|}{ OVERALL RELIABILITY SECTION 1} & & 0.80 & & \\
\hline 6 & $\begin{array}{l}\text { General management/ } \\
\text { Pure Challenge }\end{array}$ & 5 & 0.70 & 32.60 & 9.19 \\
\hline 7 & $\begin{array}{l}\text { Entrepreneurial/ } \\
\text { Creativity }\end{array}$ & 3 & 0.81 & 19.01 & 7.48 \\
\hline 8 & Geographical stability & 2 & 0.78 & 8.67 & 5.42 \\
\hline 9 & $\begin{array}{l}\text { Lifestyle/Autonomy/ } \\
\text { Independence }\end{array}$ & 4 & 0.60 & 22.76 & 7.42 \\
\hline OVERALI & LIABILITY SECTION 2 & & 0.76 & & \\
\hline
\end{tabular}


TABLE 4

EFA: Inter-correlations between dimensions

\begin{tabular}{|c|c|c|c|c|c|c|c|c|c|}
\hline Factor & $\begin{array}{c}1 \\
\text { MCE }\end{array}$ & $\begin{array}{c}2 \\
\mathrm{SE}\end{array}$ & $\begin{array}{c}3 \\
\text { Al }\end{array}$ & $\begin{array}{c}4 \\
\text { SS }\end{array}$ & $\begin{array}{c}5 \\
\text { TF }\end{array}$ & $\begin{array}{c}6 \\
\text { GMP }\end{array}$ & $\begin{array}{c}7 \\
\text { EC }\end{array}$ & $\begin{array}{c}8 \\
\text { GS }\end{array}$ & $\begin{array}{c}9 \\
\text { LAI }\end{array}$ \\
\hline $1 \mathrm{MCE}$ & 1 & & & & & & & & \\
\hline $2 \mathrm{SE}$ & $0.313^{\text {** }}$ & 1 & & & & & & & \\
\hline $3 \mathrm{Al}$ & $0.325^{* *}$ & $0.093^{* *}$ & 1 & & & & & & \\
\hline $4 \mathrm{SS}$ & $0.316^{* *}$ & $0.375^{\star \star}$ & $0.065^{\star *}$ & 1 & & & & & \\
\hline $5 \mathrm{TF}$ & $0.159^{* *}$ & $0.137^{* \star}$ & $0.185^{* *}$ & $0.237^{* *}$ & 1 & & & & \\
\hline $6 \mathrm{GMP}$ & $0.703^{* *}$ & $0.272^{\star *}$ & $0.262^{* *}$ & $0.263^{\text {** }}$ & $0.173^{\text {** }}$ & 1 & & & \\
\hline $7 \mathrm{EC}$ & $0.589^{* *}$ & $0.178^{* *}$ & $0.326^{* *}$ & 0.029 & $0.052^{* *}$ & $0.472^{\star *}$ & 1 & & \\
\hline $8 \mathrm{GS}$ & $-0.107^{\star *}$ & $-0.081^{* *}$ & $0.125^{* *}$ & $0.037^{*}$ & $0.269^{\star \star *}$ & -0.015 & $-0.060^{* \star}$ & 1 & \\
\hline $9 \mathrm{LAl}$ & $0.183^{\star \star}$ & 0.026 & $0.521^{* *}$ & 0.007 & $0.208^{* \star}$ & $0.306^{\star \star}$ & $0.301^{* *}$ & $0.286^{\star *}$ & 1 \\
\hline
\end{tabular}

${ }^{* *} p \leq 0.01$ (2-tailed) $\quad{ }^{*} p \leq 0.05$ (2-tailed)

MCE: Management/Competitiveness/Entrepreneurial

$\mathrm{SE}$ : Service/Dedication to a cause

Al: Autonomy/Independence

SS: Security/Stability

TF: Technical/Functional

GMP: General management/Pure Challeng

EC: Entrepreneurial/Creativity

GS: Geographical stability

LAl: Lifestyle/Autonomy/Independence

A principal axis factor analysis followed by a varimax rotation of the axes to simple structure was subsequently performed. The results of the analyses are reported in Tables 1 and 2. Using the conventional eigenvalue larger-than-one criterion, five factors were extracted for section 1 (cumulatively explaining $48 \%$ of the variance in the data) and four factors were extracted for section 2 (cumulatively explaining $44 \%$ of the variance in the data). The subscales for the extracted factors were obtained by calculation of the mean of the items loading on each of the subscales or factors. As shown in Table 3, each factor demonstrates acceptable internal consistency, ranging from 0.58 to 0.79 (for the five subscales of section 1, overall Cronbach alpha coefficient, 0.80 ) and ranging from 0.60 to 0.81 (for the four subscales of section 2, overall Cronbach alpha coefficient, 0.76 ).

In summary, as shown in Table 1, the exploratory factor analysis of data for this study revealed loading of items from section 1 (perceived importance of statements) onto five factors labelled in accordance with their psychological meaning and correspondence to Schein's (1978) eight-factor career anchor theory as follows: managerial and competitive/entrepreneurial opportunities which reflect a combination of items relating to the original general management; pure challenge and entrepreneurial/ creativity career anchor factors; service/dedication to a cause; autonomy/independence; security/stability and technical/ functional competence.

Table 2 shows the loading of items from section 2 (perceived agreement with statements) onto the following four factors: general management/pure challenge (a combination of items relating to the original general management and pure challenge career anchor factors); entrepreneurial/creativity; geographical stability (specific items relating to the original security/stability career anchor factor); and lifestyle/autonomy and freedom (a combination of items relating to the original lifestyle and autonomy/independence career anchor factors). Overall, the items loaded onto nine factors.

The intercorrelations (as shown in Table 4) between the nine factors are relatively low, showing no correlation between Factor 7 (entrepreneurial/creativity) and Factor 4 (security/stability); Factor 9 (lifestyle/autonomy and freedom); and Factor 2 (service / dedication to a cause); and Factor 9 and Factor 4 (security/

TABLE 5

Fit indices for Model 1 and Model $2(n=2978)$

\begin{tabular}{|c|c|c|}
\hline & $\begin{array}{r}\text { MODEL } 1 \\
\text { (ORIGINAL EIGHT- } \\
\text { FACTOR MODEL) }\end{array}$ & $\begin{array}{r}\text { MODEL 2 } \\
\text { (FIVE-FACTOR } \\
\text { MODEL) }\end{array}$ \\
\hline Degrees of Freedom & 751 & 179 \\
\hline Minimum Fit Function Chi-Square & 11849.427 & 1792.808 \\
\hline Normal Theory WLS Chi-Square & 15793.278 & 1861.164 \\
\hline RMSEA & 0.08 & 0.06 \\
\hline $\begin{array}{l}90 \text { Percent Confidence Interval } \\
\text { for RMSEA }\end{array}$ & $(0.0806 ; 0.0828)$ & $(0.0537 ; 0.0583)$ \\
\hline Non-Normed Fit Index (NNFI) & 0.88 & 0.96 \\
\hline $\begin{array}{l}\text { Parsimony Normed Fit Index } \\
\text { (PNFI) }\end{array}$ & 0.81 & 0.82 \\
\hline Comparative Fit Index (CFI) & 0.89 & 0.97 \\
\hline Incremental Fit Index (IFI) & 0.89 & 0.97 \\
\hline Goodness of Fit Index (GFI) & 0.80 & 0.94 \\
\hline $\begin{array}{l}\text { Adjusted Goodness of Fit Index } \\
\text { (AGFI) }\end{array}$ & 0.77 & 0.93 \\
\hline BIC & 9780.50 & 428.02 \\
\hline
\end{tabular}

stability). The highest intercorrelations were obtained between Factor 6 (general management/pure challenge) and Factor 1 (managerial and competitive/entrepreneurial opportunities) and Factor 7 (entrepreneurial/creativity) and Factor 1 (managerial and competitive/entrepreneurial opportunities).

\section{Confirmatory Factor Analyses (CFA)}

Preliminary single group confirmatory factor analysis was conducted on the total sample to test the extent to which the data fitted the original eight-factor measurement model developed by Schein (1978) and refined by DeLong (1982a; 1982b). As is indicated in Table 5 the NNFI, CFI, IFI and GFI values were $0.88,0.89,0.89$ and 0.80 respectively. A value of 0.90 is considered to be a good fit for all of the above indices (Hu \& Bentler, 1999). None of these values met the guideline to be regarded as acceptable. The RMSEA obtained a value of 0.08 . The guideline is that it should be at or below 0.05 (CFI > 0.90) or at or below 0.06 (CFI > 0.95) (Hayashi, Bentler \& Yuan, 2008) for a well-fitting model and at or below 0.08 for a reasonably fitting model (Hu \& Bentler, 1999). The CFI value of 0.89 indicates that 
TABLE 6

CFA: Reliability statistics $(n=2978)$

\begin{tabular}{|c|c|c|}
\hline Col Item & $\begin{array}{r}\text { Cronbach Alpha } \\
\text { Coefficient }\end{array}$ & $\begin{array}{r}\text { Cronbach Alpha } \\
\text { Coefficient if item } \\
\text { deleted }\end{array}$ \\
\hline \multicolumn{3}{|c|}{$\begin{array}{l}\text { General Management-retained } \\
\text { in Model } 1 \text { (Single Group ) } 0.82\end{array}$} \\
\hline Q2 & 0.79 & \\
\hline Q10 & 0.76 & \\
\hline Q18 & 0.76 & \\
\hline Q26 & 0.79 & \\
\hline Q26 & 0.80 & \\
\hline \multicolumn{3}{|l|}{ Q34 } \\
\hline \multicolumn{3}{|c|}{$\begin{array}{l}\text { Autonomy/Independence - retained in } \\
\text { Model1 (Single Group) } 0.71\end{array}$} \\
\hline Q3 & 0.65 & \\
\hline Q11 & 0.64 & \\
\hline Q19 & 0.64 & \\
\hline Q27 & 0.69 & \\
\hline Q35 & 0.69 & \\
\hline \multicolumn{3}{|c|}{$\begin{array}{l}\text { Service/Dedication to a cause - retained } \\
\text { in Model } 1 \text { (Single Group) } 0.78\end{array}$} \\
\hline Q5 & 0.74 & \\
\hline Q13 & 0.73 & \\
\hline Q21 & 0.73 & \\
\hline Q29 & 0.77 & \\
\hline Q37 & 0.74 & \\
\hline \multicolumn{3}{|c|}{$\begin{array}{l}\text { Pure Challenge/Competitiveness - retained } \\
\text { in Model } 1 \text { (Single Group) } 0.77\end{array}$} \\
\hline Q6 & 0.69 & \\
\hline Q14 & 0.52 & 0.52 \\
\hline Q22 & 0.61 & \\
\hline Q30 & 0.50 & 0.47 \\
\hline Q38 & 0.56 & \\
\hline \multicolumn{3}{|c|}{$\begin{array}{l}\text { Entrepreneurial/Creativity-retained } \\
\text { in Model } 1 \text { (Single Group) } 0.86\end{array}$} \\
\hline Q8 & 0.86 & \\
\hline Q16 & 0.79 & 0.82 \\
\hline Q24 & 0.79 & 0.81 \\
\hline Q32 & 0.82 & 0.86 \\
\hline Q40 & 0.80 & 0.81 \\
\hline \multicolumn{3}{|c|}{ Technical/Functional-excluded 0.61} \\
\hline Q1 & 0.61 & \\
\hline Q9 & 0.50 & 0.54 \\
\hline Q17 & 0.47 & 0.52 \\
\hline Q25 & 0.53 & 0.56 \\
\hline Q33 & 0.54 & 0.55 \\
\hline \multicolumn{3}{|c|}{ Security/Stability-excluded 0.69} \\
\hline Q4 & 0.68 & \\
\hline Q12 & 0.67 & \\
\hline Q20 & 0.61 & \\
\hline Q28 & 0.62 & \\
\hline Q36 & 0.67 & \\
\hline \multicolumn{3}{|c|}{ Lifestyle-excluded 0.46} \\
\hline Q7 & 0.42 & \\
\hline Q15 & 0.36 & \\
\hline Q23 & 0.44 & \\
\hline Q31 & 0.34 & \\
\hline Q39 & 0.46 & \\
\hline
\end{tabular}

only $89 \%$ of the covariance in the data can be reproduced by the original model for the sample. The results further indicate that the RMSEA value deems the model a reasonable to poor fit. The chi-square was 11849.427 ( $\mathrm{df} 751 ; \mathrm{p}<0.000$ ) for the sample, also indicating a poor fit.
To investigate whether the lack of fit was across the entire instrument, each sub-scale or dimension was evaluated individually. Firstly, the face validity of each item as a measure of the proposed dimension was evaluated. On face value, it did not seem that any of the items could be problematic for the target group of respondents. The students all had university exemption, and could therefore understand the content of the questions. Further, the medium of instruction was English for most students, and therefore the language used in the instrument should not have posed a challenge to the participants. Secondly, the reliability of each dimension was evaluated, and items that lowered the reliability of the dimension were removed until all items within the dimension did not lower the reliability. According to Peterson (1994), a reliability coefficient of 0.70 is desirable. Items obtaining a Cronbach alpha coefficient lower than 0.70 were therefore excluded. The reliability analyses are reported in Table 6 . In summary then, the following latent variables were retained in order to test a second model: general management competence (all five items); autonomy/ independence (all five items); service/dedication to a cause (all five items); competitiveness (only two items related to the original pure challenge career anchor subscale); and entrepreneurial/creativity (only four items from the original five items). The security/stability; lifestyle and technical/functional subscale items were deleted due to low reliability coefficients. As shown in Figure 1, Model 2 therefore consisted of only five latent variables.

Multi-group CFA was performed in order to evaluate the equivalence (invariance) of covariance matrices, number of factors, factor variances, factor covariances and factor loadings for the four race groups (Hayashi et al., 2008). Multiple group models are useful to investigate whether the same model holds in different populations, or whether there is an interaction between group membership and any aspect of a structural model. When a multiple group model is run, the estimation for all the groups proceeds simultaneously and only one chi-square statistic is printed (Hayashi et al., 2008). There were a number of missing observations, and since the missing values did not follow a consistent pattern, the EM algorithm was used to impute missing values.

As shown in Table 5, the chi-square measure for the five-factor career orientations model is highly significant and indicates a poor fit. However, given the large sample size, it would be incorrect to conclude a poor fit based on the significance of the chi-square index (Garson, 2008; Hu \& Bentler, 1999). The chi-square/df ratio was 10.02, also indicating poor fit. Ratios between 2 and 5 have been interpreted as indicating good fit (Kelloway, 1998). However, Table 5 also shows that the fit measure RMSEA has improved from 0.08 to 0.06 . Similarly, the NNFI has improved from 0.88 to 0.96 , with the IFI from 0.89 to 0.97 and the CFI from 0.89 to 0.97 . The improved CFI value indicates that $97 \%$ of the covariance in the data could be reproduced by the five-factor COI model. The GFI has also improved from 0.80 to 0.94 . This fit deems the five-factor model as well-fitting and therefore indicates (for this sample), that only a part of the COI (DeLong, 1982b; Schein, 1978;) can be regarded as a valid and reliable measure of the career orientations of the sample. The lower BIC (428.02) for the five-factor model also confirms the findings.

The structural equation model for the five factors underlying the COI is given in Figure 1. The observed variables load on one factor only. Hence the arrows depict path coefficients from these observed variables to only one latent variable or factor respectively. The path coefficients for each of the five factors vary generally from 1.00 and above, with the exception of variables 35 (0.79), 27 (0.81) and 32 (0.92).

The latent variables or factors have been allowed to correlate with one another, as is depicted by the curved arrows between them. The path coefficients show high correlations between some of the constructs. More specifically, it appears that of the 
TABLE 7

Hierarchical hypotheses and partial invariance hypotheses used for invariance testing

\begin{tabular}{ll}
\hline Hypothesis & Description \\
\hline H1 & Similar factor structure, all factor loadings free, item intercepts free, latent variances and covariances free and measurement error free across groups \\
H2 & $\begin{array}{l}\text { Similar factor structure, corresponding factor loadings and item intercepts equal across groups, latent variances and covariances free and measurement } \\
\text { error free across groups } \\
\text { Similar factor structure, corresponding factor loadings equal across groups, item intercepts free, latent variances and covariances free and measurement } \\
\text { error free across groups }\end{array}$ \\
H2A & As in H2A, except with the intercepts of items Q2, Q10, Q18, Q26 and Q34 fixed across groups (Dimension 2, General Management). \\
H2A1 & As in H2A, except with the intercepts of items Q3, Q11, Q19, Q27 and Q35 fixed across groups (Dimension 3, Autonomy/lndependence). \\
H2A2 & As in H2A, except with the intercepts of items Q5, Q13, Q21, Q29, and Q37 fixed across groups (Dimension 5, Service/Dedication to a cause) \\
H2A3 & As in H2A, except with the intercepts of items Q14 and Q30 fixed across groups (Dimension 6, Pure Challenge) \\
H2A4 & As in H2A, except with the intercepts of items Q16, Q24, Q32 and Q40 fixed across groups (Dimension 8, Entrepreneurial Creativity) \\
H2A5 &
\end{tabular}

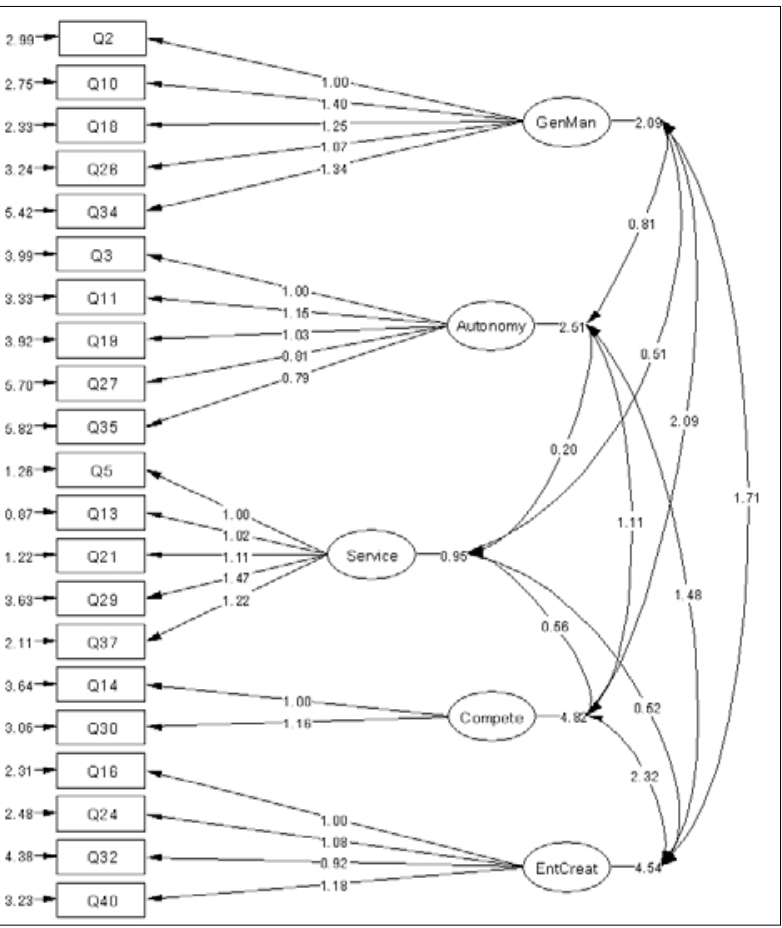

FIGURE 1

Standardised parameter estimates for five-factor $\mathrm{COI}$ model (single group)

five constructs, pure challenge/competitiveness has a strong correlation with the entrepreneurial creativity (2.32), general management (2.09) and autonomy (1.11) constructs. Moreover, entrepreneurial creativity shows a strong correlation with the general management (1.71) and autonomy (1.48) constructs. The service/dedication to a cause construct shows the lowest correlation with all four of the other constructs. In addition, a low correlation is observed between autonomy and the general management (0.81) and service/dedication to a cause (0.20) constructs.

The methodology followed for the multiple-group CFA invariance analysis follows the procedure suggested by Steenkamp and Baumgartner (1998). Invariance/equivalence testing requires the testing of a set of hierarchical hypotheses, where each subsequent test becomes increasingly restrictive. The first hypothesis to be tested (H1) tests whether similar factor structures are tenable across groups. If $\mathrm{H} 1$ is a tenable model, in the sense that an adequate fit is obtained, it can be inferred that similar dimensions across groups are confirmed in the data. The second hypothesis (H2) tests whether factor loadings and item intercepts are equal across groups, given that $\mathrm{H} 1$ was tenable. $\mathrm{H} 2$, therefore, tests $\mathrm{H} 1$ and $\mathrm{H} 2$ simultaneously. $\mathrm{H} 2$ is generally referred to as the equal metric hypothesis (Steenkamp \& Baumgartner, 1998). If $\mathrm{H} 2$ is not tenable, it is implied that although the constructs operate with equivalent dimension, the units of measure are not comparable across groups. This implies that some items may have significantly higher (or lower) loadings onto the construct they measure in some groups. When this hypothesis (H2) is rejected, it indicates that means across groups cannot be compared meaningfully. The only option then that remains for the researcher is to search for partial invariance across the models as suggested by Byrne (1998) in order to establish which sub-sections of the model could be viewed as equivalent.

Table 7 summarises the details of each hypothesis tested, whereas Table 8 summarises the fit measures for each of the hierarchical and partial invariance tests. The results of the partial invariance tests indicate that the tested hypotheses were reasonably tenable. As shown in Table 7, the NNFI, CFI and IFI values for $\mathrm{H1}$, H2, $\mathrm{H} 2 \mathrm{~A}, \mathrm{H} 2 \mathrm{~A} 1, \mathrm{H} 2 \mathrm{~A} 2, \mathrm{H} 2 \mathrm{~A} 3, \mathrm{H} 2 \mathrm{~A} 4$ and $\mathrm{H} 2 \mathrm{~A} 5$ ranged between 0.90 and 0.95 , with $\mathrm{H} 2$ obtaining the lowest values (0.91). A value of 0.90 is considered to be a good fit for all of the above indices (Hu \& Bentler, 1999). All of these values met the guideline and were therefore regarded as acceptable. With the exception of H2 - RMSEA = 0.07- all RMSEA values were 0.06 , indicating an acceptable fit. The guideline is that it should be at or below 0.05 (CFI > 0.90) or at or below 0.06 (CFI > 0.95) (Hayashi et al., 2008) for a well-fitting model and at or below 0.08 for a reasonably fitting model (Hu \& Bentler, 1999). The BIC values also show negative values, confirming the observation.

The findings suggest that the factor loadings can be regarded as similar across groups. However, since the intercepts are not equal across groups, it would be invalid to compare latent means (Strasheim, 2008). Since the conclusion at this stage broadly indicates similar latent structure across groups and equal factor loadings but not equal item intercepts, it was regarded as appropriate to test for partial invariance of intercepts, as indicated in $\mathrm{H} 2 \mathrm{~A} 1$ to $\mathrm{H} 2 \mathrm{~A} 5$ in Table 8. The results are confirmed by the group fit measures.

The guideline for SRMR values is $<0.05$ to indicate tenable hypotheses (Garson, 2008). Hu and Bentler (1999) expanded on this guideline by suggesting SRMR values lower than $<0.08$ as indicating reasonable tenable hypotheses. Table 9 shows that the SRMR values obtained for the four ethnic groups fall within the guideline of $<0.08$, indicating reasonable to mediocre tenable hypotheses. The GFI values for the African and white groups are above 0.90 (indicating a reasonable good fit), while the GFI values obtained for the Indian and coloured groups suggest a mediocre fit. Overall, these results confirm similar factor structures and equal factor loadings for particularly the African and white groups and to a lesser degree for the 
TABLE 8

Equivalence/invariance testing of model 2 across race groups

( $n=2$ 978)

\begin{tabular}{|c|c|c|c|c|c|c|c|c|}
\hline & H1 & $\mathrm{H} 2$ & $\mathrm{H} 2 \mathrm{~A}$ & H2A1 & H2A2 & H2A3 & H2A4 & H2A5 \\
\hline df & 716 & 827 & 764 & 779 & 779 & 779 & 770 & 776 \\
\hline Chi-square & 2575.5 & 3983.2 & 2696.4 & 3074.5 & 2849.5 & 2994.4 & 3132.8 & 3013.3 \\
\hline RMSEA & 0.06 & 0.07 & 0.06 & 0.06 & 0.06 & 0.06 & 0.06 & 0.06 \\
\hline $90 \%$ Confidence Interval & $\begin{array}{r}(0.06: \\
0.06)\end{array}$ & $\begin{array}{r}(0.07: \\
0.07)\end{array}$ & $\begin{array}{r}(0.06: \\
0.06)\end{array}$ & $\begin{array}{r}(0.06: \\
0.07)\end{array}$ & $\begin{array}{r}(0.06: \\
0.06)\end{array}$ & $\begin{array}{r}(0.06: \\
0.06)\end{array}$ & $\begin{array}{r}(0.06: \\
0.07)\end{array}$ & $\begin{array}{c}(0.06: \\
0.07)\end{array}$ \\
\hline NNFI & 0.94 & 0.92 & 0.95 & 0.93 & 0.94 & 0.94 & 0.93 & 0.94 \\
\hline PNFI & 0.80 & 0.89 & 0.85 & 0.85 & 0.86 & 0.86 & 0.84 & 0.85 \\
\hline CFI & 0.95 & 0.92 & 0.95 & 0.94 & 0.95 & 0.94 & 0.94 & 0.94 \\
\hline IFI & 0.95 & 0.92 & 0.95 & 0.94 & 0.95 & 0.94 & 0.94 & 0.94 \\
\hline BIC & -3151.78 & -2631.96 & -3414.85 & -3156.71 & -3381.73 & -3236.82 & -3026.42 & -3193.93 \\
\hline
\end{tabular}

TABLE 9

Group fit indices for equivalence/invariance testing $(\mathbf{n}=\mathbf{2}$ 978)

\begin{tabular}{|c|c|c|c|c|c|c|c|c|}
\hline & H1 & $\mathrm{H} 2$ & $\mathrm{H} 2 \mathrm{~A}$ & $\mathrm{H} 2 \mathrm{~A} 1$ & $\mathrm{H} 2 \mathrm{~A} 2$ & $\mathrm{H} 2 \mathrm{~A} 3$ & $\mathrm{H} 2 \mathrm{~A} 4$ & H2A5 \\
\hline \multicolumn{9}{|c|}{ AFRICAN $(n=1592)$} \\
\hline Contribution to chi-square & 884.5 & 1408.7 & 930.6 & 1055.4 & 1019.9 & 1023.8 & 1167.9 & 1070.0 \\
\hline$\%$ Contribution to chi-square & 34.1 & 35.3 & 34.4 & 33.4 & 35.5 & 33.6 & 35.9 & 34.7 \\
\hline RMR & 0.31 & 0.36 & 0.34 & 0.35 & 0.34 & 0.34 & 0.34 & 0.34 \\
\hline SRMR & 0.05 & 0.05 & 0.05 & 0.05 & 0.05 & 0.05 & 0.05 & 0.05 \\
\hline GFI & 0.95 & 0.94 & 0.95 & 0.94 & 0.95 & 0.94 & 0.95 & 0.96 \\
\hline \multicolumn{9}{|c|}{ INDIAN $(n=224)$} \\
\hline Contribution to chi-square & 407.0 & 494.7 & 427.0 & 435.9 & 444.4 & 438.2 & 443.0 & 432.8 \\
\hline$\%$ Contribution to chi-square & 15.7 & 12.4 & 15.8 & 13.8 & 15.5 & 14.4 & 13.6 & 14.0 \\
\hline RMR & 0.36 & 0.39 & 0.38 & 0.38 & 0.38 & 0.38 & 0.37 & 0.38 \\
\hline SRMR & 0.06 & 0.07 & 0.07 & 0.07 & 0.07 & 0.07 & 0.07 & 0.07 \\
\hline GFI & 0.87 & 0.85 & 0.86 & 0.86 & 0.86 & 0.86 & 0.86 & 0.86 \\
\hline \multicolumn{9}{|c|}{ COLOURED $(n=186)$} \\
\hline Contribution to chi-square & 344.0 & 414.1 & 362.6 & 384.7 & 369.4 & 369.6 & 385.5 & 368.1 \\
\hline$\%$ Contribution to chi-square & 13.3 & 10.4 & 13.4 & 12.2 & 12.8 & 12.1 & 11.9 & 11.9 \\
\hline RMR & 0.44 & 0.50 & 0.49 & 0.50 & 0.49 & 0.49 & 0.49 & 0.48 \\
\hline SRMR & 0.07 & 0.08 & 0.08 & 0.08 & 0.08 & 0.08 & 0.08 & 0.08 \\
\hline GFI & 0.85 & 0.84 & 0.84 & 0.84 & 0.84 & 0.84 & 0.84 & 0.84 \\
\hline \multicolumn{9}{|c|}{ WHITE $(n=976)$} \\
\hline Contribution to chi-square & 955.3 & 1673.5 & 984.4 & 1286.3 & 1042.2 & 1215.7 & 1253.0 & 1213.4 \\
\hline$\%$ Contribution to chi-square & 36.9 & 41.9 & 36.4 & 40.7 & 36.2 & 39.9 & 38.6 & 39.3 \\
\hline RMR & 0.30 & 0.34 & 0.29 & 0.30 & 0.29 & 0.29 & 0.29 & 0.29 \\
\hline SRMR & 0.05 & 0.05 & 0.05 & 0.05 & 0.05 & 0.05 & 0.05 & 0.05 \\
\hline GFI & 0.92 & 0.90 & 0.91 & 0.91 & 0.91 & 0.91 & 0.91 & 0.91 \\
\hline
\end{tabular}

Indian and Coloured groups. The item intercepts were found to be significantly different across all constructs, indicating that comparisons of latent variable means across the four groups are not valid. Herewith hypothesis 1 (the factor structure underlying the theoretical eight-factor career anchor model developed by Schein (1978) applies equally across various ethnic groups in the multi-cultural South African organisational context), has been partially accepted.

\section{DISCUSSION}

The aim of this study was to investigate the use of the research version of the COI (DeLong, 1982a, 1982b; Schein, 1978) as a measurement of working adults' inner career orientations within the multi-cultural South African organisational context. To achieve this aim, both exploratory and confirmatory factor analyses were performed. This approach allowed the researchers to take advantage of the relative strengths of each method in relation to those of others.
Exploratory factor analysis was applied to determine whether the underlying factor structure of the COI subscales resembled the hypothesised eight-factor original career anchor model obtained by Schein (1978). Moreover, CFA was also used to assess the construct validity of the data obtained with the COI by testing the relationships among the items or observed latent variables that comprise each of the eight career anchor constructs. The data obtained were therefore analysed in terms of the reliability of the instrument and confirmation of the observed variables deemed to measure each of the eight constructs respectively. Further, multigroup confirmatory factor analysis was performed to investigate whether the same model held for the African, coloured, Indian and white groups who participated in this study.

The findings showed that the exploratory factor analysis yielded a different factor structure (nine factors) than the five-factor structure obtained by means of the CFA procedures. These results are in line with the suggestion by Tinsley and Tinsley 
(1987) that confirmation of a hypothesised factor structure may be obtained by using CFA procedures despite a strikingly different factor structure obtained by means of exploratory factor analysis procedures. According to Van de Vijver and Poortinga (2000), confirmatory approaches provide a statistically more adequate test of the structural equivalence of multi-group data than exploratory factor analysis procedures. Compared to exploratory factor analytic procedures, CFA is a more versatile tool to test for hierarchically linked hypotheses of cross-cultural invariance. On the other hand, EFA provides the opportunity to explore the empirical data for characteristic features without imposing a definite model on the data (Madurai, Olckers \& Buys, 2008)

According to the reliability analysis conducted in the CFA, five of the eight constructs' reliability was acceptable, with estimates ranging from 0.71 to 0.85 . In terms of the pure challenge construct, the items relating to the nature of challenging problems were deleted in order to improve the reliability coefficients of the subscale. These findings are in line with Custodio (2004), who observed no pure challenge career anchors in his sample of academic executives. The items that remained as part of the subscale for the entrepreneurial creativity construct referred only to building or creating something that is entirely one's own product or idea. The general management, autonomy/ independence and service/dedication to a cause career anchor constructs were retained in the CFA best fit model (the fivefactor model), showing a similar factor structure and equal factor loadings across particularly the African and white groups and to a lesser degree across the Indian and coloured groups. As the item intercepts were found to be significantly different across all constructs, the findings indicate that comparisons of latent variable means across the four ethnic groups seem only to be valid for the African and white participants. As pointed out by Hayashi et al. (2008), the sample size could have influenced these results as African participants predominated $(n=1592)$ followed by Whites $(n=976)$, Indians $(n=224)$ and Coloureds $(n=186)$. A more heterogeneous sample in terms of age, race, gender and occupational levels might have yielded different results.

In light of the CFA best fit model, the EFA showed a number of interesting factor patterns: the general management career anchor construct items loaded on two different factors (Factor 1 and Factor 6). The items of Factor 1 (EFA managerial/entrepreneurial creativity/competitiveness) relate to the importance of being in charge of an entire organisation, rising to a high managerial position and being able to supervise, influence, lead and control people at all levels. Furthermore, Factor 1 also relates to the importance of building a new business enterprise and being able to create or build something that is entirely one's product or idea (these two items originally related to the entrepreneurial/ creativity career anchor construct). An interesting observation is the one item from the pure challenge career anchor construct that relates to the importance of competing with and beating others. These findings are in line with research conducted by Coetzee and Schreuder (2009) which indicates that having career preferences and values related to a managerial career orientation, having authority and influence and venturing out in search of new challenging opportunities positively predict the general management career anchor construct. Lee and Wong (2004) also found entrepreneurial intentions to be strongly related to the career motives of people with a general management career orientation.

The EFA Factor 7 (entrepreneurial/creativity) retained only three items of the entrepreneurial/creativity career anchor construct, namely the desire to start and build up a business on one's own; being on the lookout for ideas that would permit one to start and build one's own business; and having entrepreneurial activities as a central part of one's career. Research conducted by Coetzee and Schreuder (2009) showed that the need to have the freedom and autonomy to venture out in search of new, different and challenging job opportunities positively predict the entrepreneurial/creativity career anchor construct. These findings are also in line with Schein's (1978) finding that the master career motive underlying the entrepreneurial/creativity career anchor was the enjoyment of creating new products or services or building new (or taking over existing) organisations, together with the search for new challenges that provide a sense of freedom and power. Feldman and Bolino (2000) also found that individuals with a strong creativity anchor were motivated to become self-employed because this created the opportunity to use their skills and be creative as well as to capitalise on good business ideas.

Factor 6 consisted of the general management construct items that relate to managerial level (position) and the responsibility for supervising and integrating the efforts of others. The items of Factor 6 (EFA general management/pure challenge) also related to the pure challenge career anchor construct items that people view as being part of their career motives: competition and winning, being constantly challenged by a competitive situation and solving tough problems. Moreover, the inter-correlations of the EFA Factors general management/pure challenge (Factor 6) and general management/entrepreneurial creativity/ competitiveness (Factor 1$)$ were quite high $(\mathrm{r}=0.70 ; \mathrm{p} \leq 0.01$; large practical effect) indicating significant overlapping between the constructs. Similarly, the EFA entrepreneurial/creativity factor (Factor 7) showed a high inter-correlation with Factor 1 ( $\mathrm{r}$ $=0.59 ; \mathrm{p} \leq 0.01$; large practical effect), also indicating significant overlapping. These findings are also in line with results reported by Coetzee and Schreuder (2009) which indicate that managerial career preferences and career motives emphasising venturing out in search of new, different and challenging job opportunities, with the authority or influence to solve a variety of challenging situations or problems that require creativity, positively predict the pure challenge career anchor construct. Moreover, the strong correlations between the entrepreneurial/creativity, general management, pure challenge/competitiveness and autonomy constructs obtained in the CFA generally confirm the overlapping values and motives observed for these four constructs.

It is interesting to observe that in terms of the EFA Factor 2 (service/dedication to a cause) only three items - those relating to the use of one's interpersonal and helping skills to make the world a better place, and to serve an important cause - were retained. However, in terms of the CFA best fit (fivefactor) model, the service/dedication to a cause career anchor construct also included the two items relating to seeking a career in which one can be of service to others and in which one can be committed to an important cause. Coetzee and Schreuder (2009) found in this regard that having a strong sense of career purpose or viewing one's career as a calling (and not merely as a job or career) and developing one's self-management and relationship skills positively predict the service/dedication to a cause career anchor construct. Moreover, having the ability to form positive and supportive social networks and being driven by a need for personal growth and development were also shown to positively predict this career anchor construct. The low correlations observed in the CFA for the service/dedication to a cause construct and the other four constructs also confirm the independence of the service/dedication to a cause construct, indicating a unique set of career values and motives.

The construct 'lifestyle' yielded the lowest reliability (0.46), followed by the technical / functional (0.59) and security/stability $(0.68)$ constructs. These subscales each showed two underlying dimensions within the subscale. The lifestyle career anchor construct related to the following two underlying dimensions: developing and maintaining a lifestyle that balances one's career and family needs (deleted items in the EFA) and having the freedom and autonomy to choose and maintain a certain lifestyle (EFA Factor 9). According to Schein (1978), the core motive underlying the lifestyle career anchor construct was that of valuing company benefits that allow flexible work arrangements 
and options. It is interesting to observe that two of the four items of Factor 9 (EFA) relate to one's sense of freedom and autonomy and being unconstrained by either an organisation or business world (Factor 9). These two items originally related to the COI autonomy/independence career anchor construct. However, all the items relating to the autonomy/independence career anchor construct were retained in the CFA. It is also interesting to note that the EFA Factor 9 (lifestyle/autonomy/freedom) showed a relatively high correlation $(\mathrm{r}=0.52 ; \mathrm{p} \leq 0.01$; large practical effect) with the autonomy/independence (EFA Factor 3) construct. This also suggests an overlap between the two career orientation constructs. Research findings reported by Coetzee and Schreuder (2009) also show that a preference for freedom and autonomy and valuing being in a position of authority and influence positively predict the lifestyle career orientation.

The security/stability construct related to the following two dimensions: security provided by means of organisational benefits and long-term stability (EFA Factor 4) and security/ stability regarding geographical location (EFA Factor 8). These findings are in line with research conducted by DeLong (1982a) who identified geographical security as an additional career anchor construct. Custodio (2004) also identified the same two underlying factor structures for the security/stability career anchor construct. Research conducted by Coetzee and Schreuder (2009) indicates that participants with a security/stability career orientation have a higher need for steady employment in their area of expertise and a lower need for career venturing and being exposed to new, different and challenging job opportunities. It is interesting to observe that the item relating to tenure (lifetime employment) was deleted in the exploratory factor analysis. The findings also suggest a shift in participants' inner career orientations, namely a move away from lifetime employment to lifestyle concerns in the form of geographical location and benefit packages (Kniveton, 2004). This could be due to the predominance of female participants who may have family concerns or responsibilities. Generally these findings confirm the master career motive driving the security/stability career anchor construct to be that of having long-term stable, steady employment with benefit packages that offer security regarding medical and retirement concerns, and not necessarily lifetime employment (Schein, 1978).

The technical/functional construct related to two underlying dimensions, namely opportunity to specialise in an area of expertise, and potential for promotion, at the expense of remaining in one's area of expertise. It must be noted that only the two items related to remaining in one's area of expertise or specialisation loaded onto the factor technical/functional in the exploratory factor analysis. The items relating to promotion were deleted. This finding confirms the master career motive identified by Schein (1978) for the technical/functional career anchor construct as being building one's career around one's expertise and being exposed to opportunities to apply one's talents and skills. Research by Coetzee and Schreuder (2009) also shows that individuals with a technical/functional career orientation had a lower need for career venturing and being exposed to a variety of challenges. They appear to have a higher need for stability and security and being paid for their skills levels. Growth and development opportunities to enhance their expertise are more important than being promoted into other positions (Schein, 1978).

Overall, the inter-correlations of the nine-factor solution obtained by means of the EFA were relatively low, pointing to the independence of the obtained factors. Career orientation factors that are independent of one another provide a meaningful framework for explaining individuals' inner career orientations and this was satisfactorily achieved in the present study. However, as previously pointed out and as also observed for the CFA, some of these factors showed high inter-correlations, suggesting some overlap between the constructs measured.

\section{Conclusion, limitations and recommendations}

It appears from the EFA that the career orientations of the participants relate to different aspects of the master career motives that underlie the general management, pure challenge and entrepreneurial/creativity career anchor constructs. This finding is contrary to Schein's (1978) argument that people tend to have one dominant career anchor and is more in line with Feldman and Bolino's (1996) observation that one to three career anchors tend to cluster together to form an individual's career and work preferences. Coetzee and Schreuder (2009) also found that a number of career-related preferences, values, skills and attitudes drive or predict people's career anchors or career orientations. It appears therefore from the findings of this research that the career self-concept as originally defined by Schein (1978) might have evolved over time in line with the shifts reflected in the global socio-economic and socio-demographic profiles of organisations and societies. Similar observations have been made by Havran et al. (2003); Kniveton (2004) and Marshall and Bonner (2003).

The research confirms the need for assessing the inner career orientations of employees as these provide a richness of valuable information regarding the motives and values driving individuals' career decision-making. Individuals' master career motives and values form an integral part of their career consciousness. Career consciousness includes people's conscious, career-related cognitions (that is, perceptions, awareness and self-evaluations) of their career preferences or orientations, values, skills, attitudes and behaviours that are understood and regarded by people as being helpful in realising their goals and achieving career success (Coetzee, 2007). Since research (Coetzee et al., 2007; Coetzee \& Schreuder, 2008; Kanye \& Crous, 2007) has shown that employees' inner career orientations are related to their life satisfaction, job/career satisfaction, organisational commitment, performance and motivation, it is suggested that both quantitative and qualitative measures be employed to gain deeper insight into the broader career consciousness of the individual.

These findings also suggest the need for further refinement of the items relating to each subscale of the COI, particularly for the South African organisational context. Moreover, it must be pointed out that the reliability coefficient cut-off value set for the purpose of this research was quite stringent. Although Nunnaly and Bernstein (1994) use 0.70 as a directive, Bartholomew, Antonia and Marcia (2000) argue that between 0.60 and 0.80 is acceptable. Tredoux and Durrheim (2002) also suggest that reliabilities as low as 0.30 are quite acceptable in the case of individual testing when instruments are used to gather group data. This suggests that the COI could be deemed as acceptable in the South African organisational context when being used to obtain group data. However, in the case of individual testing situations, industrial psychologists and career practitioners must take note of the occupational context and the unique characteristics of the respondent when applying the COI. Qualitative data gathering by means of an in-depth interview (as suggested by Schein, 1990) should complement individual assessment. Herewith the research hypothesis $\mathrm{H} 2$ (the researchversion of the COI developed by Schein, in collaboration with DeLong (1982a; 1982b), can be applied as a measure to determine the career orientations of working adults in the South African organisational context) is rejected with regard to individual assessments and accepted with regard to broad group-based measures.

The practical value of the research findings lies in confirming the importance of considering the diverse career needs of employed adults in South Africa's multi-cultural work environment. Marshall and Bonner (2003) contend that organisations need people with divergent career anchors, since this provides organisations with a flexible and diverse workforce. In this regard, the notion of career anchors provides organisations with a 
valuable framework to help them offer employees opportunities that are congruent with their career orientations. Brousseau, Driver, Eneroth and Larsson (1996) also confirm the need to follow a pluralistic approach to career development practices to meet employees' diverse needs. As Morrin (cited in Custodio 2004:9) says, an individual's career success depends on the extent to which organisations allow their employees to succeed on their own terms within the context of organisational needs. While individuals should have an awareness and knowledge of their unique career needs, motives and goals so they can work out how to align these with the organisation's needs, organisations themselves must find a way to inspire, motivate, and appropriately reward employees for higher productivity.

The research findings provided a preliminary perspective on the value of the COI in measuring employees' inner career orientations. However, some limitations and recommendations must be borne in mind concerning the findings of this study. The demographic profile of the sample warrants caution in generalising the results to the larger population. Replicating the study by including a more heterogeneous sample across various occupational groups and industries as well as employing a more refined version of the COI along with other measures of career orientations may add more in-depth insight into the dynamics of employees' inner career orientations. Further research of this nature could result in revised theoretical models of career orientations and add to one's understanding of how these manifest across various cultural or ethnic, age and gender groups. Future validation studies could also focus on improving the model fit of the theoretical model underpinning the measure of career orientations used in this research.

\section{REFERENCES}

Bartholomew, K., Antonia, J.Z., \& Marcia, J.E. (2000). Coded semi-structured interviews in psychological research. In H.T. Resi \& C.M. Judd (Eds.), Handbook of research methods in social and personality psychology, (pp. 286-312). Cambridge: Cambridge University Press.

Boshoff, A.B., Bennett, H.F., \& Kellerman, A.M. (1994). Career orientations as predictors of the level of job involvement of professional people. Journal of Industrial Psychology, 2(2), 8-13.

Brousseau, K.R., Driver, M.J., Eneroth, K., \& Larsson, R. (1996) Career pandemonium: Realigning organisations and individuals. Academy of Management Excecutive, 10(4), 82107.

Brown, M.W., \& Cudeck, R. (1993). Alternative ways of assessing model fit. In K.A. Bollen \& J.S. Long (Eds.), Testing structural equation models, (pp. 136-162). Newsbury Park: Sage.

Bruck, C.S., Allen, T.D., \& Spector, P.E. (2002). The relationship between work-family conflict and job satisfaction: A finergrained analysis. Journal of Vocational Behavior, 60, 336-353.

Burke, R.J. (1983). Career orientations of Type A individuals. Psychological Reports, 53, 979-989.

Butler, T., \& Waldroop, J. (1999). Job sculpting: The art of retaining your best people. Harvard Business Review, September/October, 144-152.

Byrne, B.M. (1998). Structural equation modelling with LISREL, PRELIS and SIMPLIS: Basic concepts, applications and programming. London: Lawrence Erlbaum Associates.

Cannon, D. (1995). Generation X and the new work ethic. London: Demos.

Casey, C. \& Alach, P. (2004). "Just a temp?" Women, temporary employment and lifestyle. Work, Employment E Society, 18(3), 459-480.

Child, D. (1990). The essentials of factor analysis. (2nd edn.). London: Cassell Educational.

Coetzee, M., \& Schreuder, A.M.G. (2007). Exploring the career anchors, life satisfaction and job/career satisfaction of working adults. Unpublished manuscript.

Coetzee, M., \& Schreuder, A.M.G. (2008). A multi-cultural investigation of students' career anchors at a South African higher education institution. SA Journal of Labour Relations, 32(2), 1-21

Coetzee, M., \& Schreuder, A.M.G. (2009). Psychological career resources as predictors of working adults' career anchors: An exploratory study. Unpublished research report, University of South Africa, Pretoria, South Africa.

Coetzee, M., Schreuder, A.M.G., \& Tladinyane, R. (2007) Organisational commitment and its relation to career anchors. Southern African Business Review, 11(1), 65-86.

Custodio, L.P. (2004). Career anchors of Filipino Academic Executives. Philippines: School of Commerce Research Paper Series: 00-13: College of Business and Accountancy.

DeLong, T.J. (1982a). The career orientations of MBA Alumni: A multi-dimensional model. In R. Katz (Ed.), Career Issues in Human Resource Management, (pp. 50-64). Upper Saddle River: Prentice Hall.

DeLong, T.J. (1982b). Reexamining the career anchor model. Personnel, 59(3), 60-61.

Derr, C.B. (1980). Work, family and the career: New frontiers in theory and research. New York: Praeger.

Derr, C.B. (1986). Managing the new careerist: The diverse career success orientations of today's workers. San Francisco: JosseyBass.

Derr, C.B., \& Briscoe, J.P. (2007). The catalyctic 1970s: Lessons for the 2000s. In H. Gunz \& M. Peiperl (Eds.), Handbook of career studies, (pp. 528-541). London: Sage.

Dooley, D. (1995). Social research methods. Upper Saddle River: Prentice Hall.

Driver, M.J. (1982). Career concepts: A new approach to career research. In R. Katz (Ed.), Career issues in human resource management, (pp. 23-32). Englewood Cliffs: Prentice Hall.

Erdoğmus, N. (2003). Career orientations of salaried professionals: The case of Turkey. Career Development International, 9(2), 153-175.

Erwee, R. (1990). Career anchor profiles of a sample of business and professional women. Journal of Industrial Psychology, 16(1), 5-12.

Fabrigar, L.R., Wegener, D.T., MacCallum, R.C., \& Strahan, E.J (1999). Evaluating the use of exploratory factor analysis in psychological research. Psychological Methods, 4(3), 272-299.

Feldman, D.C., \& Bolino, M.C. (1996). Careers within careers: Reconceptualising the nature of career anchors and their consequences. Human Resource Management Review, 6(2), 89-112.

Feldman, D.C., \& Bolino, M.C. (2000). Career patterns of the selfemployed: Career motivations and career outcomes. Journal of Small Business Management, 38, 53-67.

Fugate, M., Kinicki, A.J., \& Ashforth, B.E. (2004). Employability: A psycho-social construct, its dimensions and applications. Journal of Vocational Behaviour, 65, 14-38.

Garson, G.D. (2008). Structural Equation Modeling: Statnotes, PA765. Retrieved 12 January, 2009, from http://faculty.chass. ncsu.edu/garson/PA765/structur.html

Guest, D.E., \& Sturges, J. (2007). Living to work - working to live: Conceptualisations of careers among contemporary workers. In H. Gunz \& M. Peiperl (Eds.), Handbook of career studies, (pp. 310-326). London: Sage.

Hall, D.T. (1976). Careers in organisations. Pacific Palisades: Wiley.

Havran, H., Visser, D., \& Crous, F. (2003). The internal career orientations of permanent and contracting information technology staff. SA Journal of Industrial Psychology, 29(3), 53-60.

Hayashi, K., Bentler, P.M., \& Yuan, K.H. (2008). Handbook of statistics (Vol. 27). New York: Elsevier.

Herr, E.L., Cramer, S.H., \& Niles, S.G. (2004). Career guidance and counseling through the lifespan. London: Prentice Hall.

Hewlett, S.A., \& Luce, C.B. (2005). Off-ramps and on-ramps. Harvard Business Review, 83(3), 43-54.

Hoyle, R.H. (1995). Structural equation modeling: Concepts, issues and applications. Thousand Oaks: Sage.

Hox, J.J., \& Bechger, T.M. (1998). An introduction to structural equation modeling. Family Science Review, 11, 354-373. 
Hu, L.T., \& Bentler, P.M. (1999). Cut-off criteria for fit indices in covariance structure analysis: Conventional criteria versus new alternatives. Structural Equation Modeling, 6(1), 1-55.

Järlström, M. 2000. Personality preferences and career expectations of Finnish business students. Career Development International, 5(3), 144-154.

Jiang, J.J., \& Klein, G. (2000). Supervisor support and career anchor impact on the career satisfaction of the entry-level information systems professionals. Journal of Management Information Systems, 16(3), 219-240.

Jiang, J.J., Klein, G., \& Balloun, J.L. (2001). The joint impact of internal and external career anchors on entry-level IS career satisfaction. Information and Management, 39, 31-39.

Kanye, B., \& Crous, F. (2007). Graduate interns' experiences: A career success orientations approach. SA Journal of Industrial Psychology, 33(3), 84-93.

Kelloway, E.K. (1998). Using LISREL for structural equation modeling: A researcher's guide. Thousand Oaks: Sage.

Kniveton, B.H. (2004). Managerial career anchors in a changing business environment. Journal of European Industrial Training, 28(7), 564-573.

Kuijpers, M.A.C.T. \& Scheerens, J. (2006). Career competencies for the modern career. Journal of Career Development, 32(4), 303-319.

Lee, S.H., \& Wong, P.K. (2004). An exploratory study of technopreneurial intentions: A career anchor perspective. Journal of Business Venturing, 19(7), 7-28.

Madurai, M., Olckers, C., \& Buys, M. (2008). The construct validation of an instrument designed to assess organisational socialisation. SA Journal of Industrial Psychology, 34(1), 1-9.

Marshall, V., \& Bonner, D. (2003). Career anchors and the effects of downsizing: Implications for generations and cultures at work: A preliminary investigation. Journal of European Industrial Training, 27(6), 281-291.

Nunnaly, J.C., \& Bernstein, I.H. (1994). Psychometric theory. New York: McGraw-Hill.

Owen, K. (1995). Test bias and test fairness. In K. Owen \& J.J. Taljaard (Eds.), Handbook for the use of psychological and scholastic tests of the HSRC. Pretoria: Human Sciences Research Council.

Peterson, R.A. (1994). A meta-analysis of Cronbach's coefficient alpha. Journal of Consumer Research, 21, 381-391.

Raftery, A. (1995). Bayesian model selection in social research. Sociological Methodology, 25, 111-163.

Ramakrishna, H.V. \& Potosky, D. (2002). Structural shifts in career anchors of Information Systems Personnel: A preliminary empirical analysis. The Journal of Computer Information Systems, 42(2), 83-89.

Ramakrishna, H.V., \& Potosky, D. (2003). Conceptualisation and exploration of composite career anchors: An analysis of Information Systems Personnel. Human Resource Development Quarterly, 14(2), 199-214.

Raykov, T. \& Marcoulides, G.A. (2000). A first course in structural equation modelling. Mahwah: Lawrence Erlbaum Associates.

Rothmann, S. (2001). Die verband tussen die persoonlikheidsvoorkeure en loopbaanankers van bestuurders. Bestuursdinamika, 10(2), 67-89.
Salkind, N.J. (1997). Exploring research. Fort Worth: Harcourt Brace.

Shaughnessy, J.J., \& Zechmeister, E.B. (2003). Research methods in psychology. New York: McGraw-Hill.

Schein, E.H. (1974). Career anchors and career paths: A panel study of management school graduates. Technical report No. 1. Cambridge, MA: Sloan School of Management.

Schein, E.H. (1975). How "career anchors" hold executives to their career paths. Personnel, 52(3), 11-24.

Schein, E.H. (1978). Career dynamics: Matching individual and organizational needs. Boston, MA: Addison-Wesley.

Schein, E.H. (1990). Career anchors: Discovering your real values. San Diego: Pfeiffer \& Company.

Schein, E.H. (1996). Career anchors revisited. Implications for career development in the 21st century. Academy of Management Executive, 1, 80-88.

Schenk, H.W.E. (1987). Die werkwaardes en beroepsoriëntasies van gegradueerde ingenieurs in twee werkgewersektore. Ongepubliseerde M-verhandeling, Randse Afrikaanse Universiteit, Johannesburg, Suid-Afrika.

Schreuder, A.M.G. (1989). Die verwantskap tussen loopbaananker, beroepstipe, organisasietipe en gehalte van werklewe. Ongepubliseerde DAdmin proefskrif, Universiteit van SuidAfrika, Pretoria, Suid-Afrika.

Steenkamp, J.E., \& Baumgartner, H.B. (1998). Assessing measurement invariance on cross-national consumer research. Journal of Consumer Research, 25, 78-90.

Strasheim, C. (2008). Simultaneous normalisation as an approach to establish equivalence in cross-cultural marketing research. Unpublished PhD thesis, University of the Witwatersrand, Johannesburg, South Africa.

Suutari, V., \& Taka, M. (2004). Career anchors of managers with global careers. Journal of Management Development, 23(9), 833-847.

Tinsley, H.E.A., \& Tinsley, D.J. (1987). Using factor analysis in counseling psychology research. Journal of Counseling Psychology, 34, 414-424.

Tredoux, C., \& Durrheim, K. (2002). Numbers, hypotheses $\mathcal{E}$ conclusions: A course in statistics for the social sciences. Cape Town: UCT Press.

Valcour, M., Bailyn, L., \& Quijada, M.A. (2007). Customised careers. In H. Gunz \& M. Peiperl (Eds.), Handbook of career studies, (pp. 188-210). London: Sage.

Vandenberg, R.J., \& Lance, C.E. (2000). A review and synthesis of the measurement invariance literature: Suggestions, practices and recommendations for organisational research. Organisational Research Methods, 3(1), 4-69.

Van de Vijver, F.J.R., \& Poortinga, Y.H. (2000). Structural equivalence in multilevel research. Tilburg: Tilburg University.

Van Vuuren, L.J. (1986). Die beroepsoriëntasie van professionele rekenkundige persone tydens die vroeë beroepsjare. Ongepubliseerde M-verhandeling, Randse Afrikaanse Universiteit, Johannesburg, Suid-Afrika.

Wood, L., Winston, R.B. Jr., \& Polkosnik, M.C. (1985). Career orientations and professional development of young student affairs professionals. Journal of College Student Personnel, 26(6), 533-538 